\title{
Medical arguments for and against the liberalization of doping
}

\section{Pedro Manonelles Marqueta ${ }^{1,2}$, Carlos De Teresa Galván³, José Antonio Lorente Acosta ${ }^{3}$, Juan José Rodríguez Sendín ${ }^{4}$, Serafín Romero Agüit' ${ }^{4}$, José Luis Terreros Blanco ${ }^{5}$}

'Spanish Society of Sports Medicine. ${ }^{2}$ San Antonio Catholic University of Murcia. ${ }^{3}$ University of Granada. ${ }^{4}$ General Council of Official Colleges of Physicians. ${ }^{5}$ Spanish Agency for the Protection of Health in Sport.

doi: 10.18176/archmeddeporte.00016

Received: $26 / 05 / 2020$

Accepted: $11 / 11 / 2020$

Key words:

Doping prohibition. Liberalization. Health. Medical ethics. Medical deontology.

\section{Summary}

The use of doping has been banned for almost a century due to the risk involved to the athlete's health. Since then, the criterion of prohibiting substances has been reinforced to improve performance, becoming a rarely controversial issue nowadays. However, opinions defending the liberalization of doping has been sometimes given based on various arguments. One of the most common is the impossibility of completely eradicating doping and that this can be safe, from the point of view of health, if it is done by qualified doctors.

This paper presents the arguments against the liberalization of doping from a medical point of view, contemplating various aspects.

Those related to the use of substances such as: lack of clear criteria for inclusion in the list of prohibited substances and the unclear margin between the use of medication for treatment and for doping.

Arguments related to health protection such as: the risk of sport for the athlete, the healthy sport, doping substances have few health risks, the use of medications, allow genetic doping because it is inevitable, risks of self-medication or use of medication without a prescription.

Arguments related to sports performance such as: Doping products do not improve performance, doping is comparable to other performance improvement techniques, match genetic differences among athletes.

And other arguments such as: prohibition favours doping, the control of doping increases the risks of doping itself, the high cost of anti-doping fight or the few anti-doping resources.

The proposal for liberalization of doping under medical control is analyzed and discussed as well as the effects of liberalization on children and adolescents. At the end the medical ethical aspects related to doping are presented to conclude with the opposition of the medical profession against doping and its liberalization.
Palabras clave:

Prohibición del dopaje. Liberalización.

Salud. Ética médica. Deontología médica.

\section{Argumentos médicos a favor y en contra de la liberalización del dopaje}

\section{Resumen}

El dopaje está prohibido desde hace casi un siglo debido al riesgo que implica para la salud del deportista. Desde entonces, el criterio de prohibición de sustancias se ha reforzado para mejorar el rendimiento, convirtiéndose en un tema poco controvertido en la actualidad. Sin embargo, a veces se han emitido opiniones en defensa de la liberalización del dopaje basadas en diversos argumentos. Uno de los más habituales es la imposibilidad de erradicar por completo el dopaje y que éste puede ser seguro, desde el punto de vista de la salud, si lo practica médicos titulados.

Este artículo presenta los argumentos en contra de la liberalización del dopaje desde el punto de vista médico, contemplando diversos aspectos.

Los relacionados con el uso de sustancias tales como: falta de criterios claros para su inclusión en la lista de sustancias prohibidas y el margen poco claro entre el uso de medicamentos para tratamiento y dopaje.

Argumentos relacionados con la protección de la salud como: el riesgo del deporte para el deportista, el deporte sano, las sustancias dopantes tienen pocos riesgos para la salud, el uso de medicamentos, permitir el dopaje genético porque es inevitable, los riesgos de automedicación o uso de medicación sin prescripción.

Argumentos relacionados con el rendimiento deportivo tales como: los productos antidopaje no mejoran el rendimiento, el dopaje es comparable a otras técnicas de mejora del rendimiento, diferencias genéticas entre los deportistas.

Y otros argumentos como: la prohibición favorece el dopaje, el control del dopaje aumenta los riesgos del dopaje, el alto coste de la lucha antidopaje o los escasos recursos antidopaje.

Se analiza y discute la propuesta de liberalización del dopaje bajo control médico y los efectos de la liberalización en niños y adolescentes. Al final se presentan los aspectos éticos médicos relacionados con el dopaje para concluir con la oposición de la profesión médica al dopaje y su liberalización. 


\section{Introduction}

The origin of the fight against doping can be attributed to the International Amateur Athletic Federation (IAAF) that in 1928 prohibits the use of doping, and specifically the use of stimulants ${ }^{1}$. The International Olympic Committee, in 1960, set up the first Anti-Doping Commission and, together with some international sports federations, established the reasons for the anti-doping policy that are: to maintain and preserve the ethics of sport, to guarantee the physical health and mental integrity of the players and ensure that all competitors have an equal opportunity to compete ${ }^{2}$. Nowadays, the institution responsible for the World Anti-Doping Program is the World Anti-Doping Agency (WADA-AMA) with the legal support of UNESCO ${ }^{3}$, which highlight that the purposes of the World Anti-Doping Code ${ }^{4}$ the athletes' fundamental right to participate in doping-free sport, to promote health, and thus to ensure fairness and equality in sport for all athletes around the world.

However, there is still a debate as to whether it would not be better to liberalise their use and leave the decision on whether or not to doping to the athlete's discretion, rather than taking all the measures involved in implementing anti-doping regulations

Doping tests are not supposed to identify all athletes using doping substances or methods ${ }^{5-7}$. Doping is more widespread than is indicated by reports of adverse analytical results (AAR) from laboratories accredited by the World Anti-Doping Agency (WADA) ${ }^{8}$ and as reflected in surveys of anti-doping attitudes and behaviour ${ }^{9}$. Thererfore, is a strong suspicion that some sporting achievement is achieved through doping ${ }^{10}$.

Some authors believe that due to the fact that current rules have failed to prevent doping, and it is much more prevalent than the current data reflects, doping probably could not be eradicated. From this point of view, liberalising the use of prohibited substances would be the best way of avoiding the problem of doping ${ }^{10-13}$. But, on the other hand, the supporters of this proposal realise that a total liberalisation of doping would have major risks for the health of the general public, affecting a very large number of subjects ${ }^{12}$, including amateur athletes who already have an alarming and very high prevalence of doping use $\mathrm{e}^{14-17}$. As a final proposal by these authors, performance-enhancing drugs should be allowed under medical supervision in elite athletes ${ }^{12}$.

This document presents the arguments for and against the liberalisation of doping that relate to health aspects, as well as the position of sports medicine in relation to the proposal to create a doping system by doctors.

\section{Arguments related to the use of substances and prohibited methods}

\section{Lack of clear criteria for inclusion in the list of prohibited substances}

\section{Lack of clear criteria for inclusion on the list of prohibited substances}

One argument used by supporters of liberalization is that the criteria for inclusion on the lists of banned substances are unclear ${ }^{11,13}$. Criticism has been made of allowing the use of painkillers such as paracetamol ${ }^{11}$ since it might improve the athlete's physical capacity. However, there are scientific proof tha paracetamol is an analgesic that does not improve performance and the athlete has the right to treat painful conditions. Surprisingly, the better knowledge of the use of some substances leads to findings that could force a reconsideration of the banning of substances such as painkillers, as it has been found that pre-competition users of painkillers may be particularly prone to the use of doping substances ${ }^{18}$

The removal of caffeine from the lists of banned substances after it had been banned for years has also been criticised ${ }^{11}$. There is also criticism of other substances such as nicotine or tetrahydrocannabinol ${ }^{12,19}$

When analysed anaylse these substances, there is only evidence of performance enhancement in the case of caffeine ${ }^{20}$ and possibly their non-inclusion on the banned list is due to the widespread use of coffee, given that $75 \%$ of sportsmen and women consume coffee before or during competition, but only $0.6 \%$ have urinary concentrations above $12 \mu \mathrm{g}-\mathrm{mL}^{-1}$, which could be a high concentration ${ }^{21}$. In addition, the WADA monitoring program does not show significant consumption for doping purposes 22 .

More research is needed to provide greater evidence of any harmful effects of performance-enhancing technologies to deter potential users rather than coerce them. Additional actions might include placing substances on the banned lists with greater knowledge of their effects ${ }^{23}$ and also carrying out doping controls more effectively?

\section{The blurred margin between the use of medication for treatment and for doping}

It has been argued that medical treatment for athletes can be problematic when there is a need to use medicines included in the doping list, even if outside the sporting context these are medicines for regular and licit clinical use. It has also been argued that the system of therapeutic use exemptions (TUE) ${ }^{24}$ is expensive and may in some cases deprive the athlete of adequate treatment ${ }^{25}$. In some cases, there have been difficulties in treating some athletes, as was the case with the use of beta2-agonists for the management of asthma ${ }^{26}$. However this case has now been resolved by allowing the use of most of these preparations in clinical and inhalation doses without limitation. Additionally, the TUE system has been questioned since it is suspected that it might be a way of favouring the use of substances, not for therapeutic purposes but for doping ${ }^{27}$.

Doping has also been criticised by questioning whether so-called performance enhancing treatments are banned for athletes but allowed for other individuals, whether there are any relevant differences between therapeutic and performance enhancing treatments, and whether bans on performance enhancing treatments should be reconsidered on the basis of sporting disciplines ${ }^{11}$.

The first years of application of anti-doping regulations resulted in a time when certain medications could not be used for the legitimate and fully justified treatment of certain pathologies in athletes. The implementation of the TUE system was an enormous success that has allowed Medicine to treat patients, even if they are athletes, with prohibited medications, following the established rule which, in general terms, is adequate and sufficient. 
What cannot be agreed upon is the differentiation between treatments for therapeutic purposes and those for improvement. In medicine there are prescription criteria for processes and diseases that are established by medical practice and evidence. There are no indications for improving treatment and, very possibly, the performance of this type of action by the doctor could be considered malpractice and, therefore, susceptible to constitute a lack of ethics.

The use of doping substances for therapeutic purposes has been suggested as a way of avoiding the consequences of sporting activity ${ }^{28}$ and would be designed to protect the athlete from the potential great damage that training and the competitive calendar cause at such high levels of competition.

This therapeutic concept does not exist in clinical practice and the allegedly serious consequences of competitive sport have not been described either.

\section{Arguments related to health protection}

\section{The argument of the risk of sport for the athlete}

One of the arguments for banning doping is to protect the health of the athlete.

Supporters of liberalisation have several objections to this. They point out that, since sport has even fatal risks, there is no justification for using this argument in favour of control of doping. They consider that the argument of the health of the athlete is paternalistic and is not in agreement with the unhealthy aspects and risks associated with the practice of elite sport ${ }^{23}$. They understand that there is no knowledge of possible future harmful effects ${ }^{29}$. Finally, the abolitionists say that the argument for banning doping on health grounds, as is the case with banning alcohol from driving vehicles, is not an argument for banning doping because driving under the influence of alcohol endangers the lives of others and is therefore a public health offence, and this does not seem to be the case with doping. For them, what is dangerous is not the use of doping procedures, such as the use of substances or even blood transfusion, but the clandestiny, without medical supervision and without the athlete being aware of the risks and possible future effects. In addition, due to the fact that harmful effects on health may be greater with a ban than with tolerance accompanied by medical supervision and information to athletes, they justify liberalisation since this would considerably reduce the risks ${ }^{11,29}$.

Sport is an activity whose essence is competition ${ }^{30}$, which places the athlete at the limit or above his possibilities and therefore generates risks that are inherent to sport itself. This is why the federations adopt rules to reduce the risks and not to take new risks, such as doping. It is precisely because of the risk inherent in sport that the argument for banning doping is fully justified so as not to add to the risks to the athlete beyond those already posed by the sport itself. Moreover, the risks of doping are additional and avoidable, whereas some of the risks of sport are unavoidable ${ }^{31}$ such as in diving, combat sports, caving, mountaineering and motor sports.

Moreover, the use of some doping substances is not only a risk to the health of the athlete who is doping, but also to others, for example:

- Cocaine and anabolics increase the aggressiveness of the sportsman or woman over other sportsmen or women. It could involve a risk in boxing and other combat sports, fencing, olympic shooting, archery and biathlon.

- Narcotics, by lowering the level of awareness, can endanger the lives of other athletes or other people (climbing, mountaineering, caving, canoeing, bobsleigh) and in circumstances that make the athlete lose control and impact on other athletes or spectators as in motor sports (motor racing, motorcycling, jet skiing, even cycling).

- The same applies to other products that lower the level of attention of the sportsman or woman.

Doping also has other effects on others. Some athletes resort to doping because they are certain that their opponents are doping, and if they do not do so too, they will be at a disadvantage (2. $^{32}$ This is the socalled coercion or "moral damage" argument ${ }^{33}$ whereby the depositor who dopes harms "clean" depositors by forcing them to dope, which is a form of coercion that harms others and is a further argument for refusing doping. According to this argument, doping should be banned because it forces athletes to use it if they want to compete at higher levels. Since clean athletes are being coerced into doping, they are not fully responsible for their actions. Thus, if they cannot withstand the pressure exerted on them both by other competitors and by the elite sport system itself, they are not autonomous in their actions. Only the intervention of sports institutions can protect their autonomy and allow them to decide not to use drugs when competing at elite level. Rejection of doping therefore safeguards the autonomy of competitors.

Moreover, athletes who are convinced that their opponents are doping are the most vulnerable group to use doping procedures ${ }^{34}$.

Finally, a risk for the athlete would be that they would be pushed into doping without being clearly indicated that he is being doped, which can happen in two circumstances:

- Children. As occurred in the former German Democratic Republic ${ }^{35}$, which had very serious consequences. At least one case of sex change from woman to man, the virilizations of anabolized women, has been known and the pain of muscular rigidity experienced by children when subjected to processes of anabolization, to name only a few, has been described.

- Adults. In general, the athlete has knowledge and experience and the minimum commitment to knowledge at least of the doping rules is assumed so that he or she is not misled by others into doping. However, it may be that in some cases there is a lack of vigilance in the advice given to him or her to take substances and get caught up in a doping procedure.

It is therefore important that there is a procedure for checking that athletes are not being exploited by others ${ }^{36}$. It should be remembered that athletes have confidence in the people around them, who are not always totally concerned with their well-being and may be the ones who lead them to take drugs in order to maintain performance, bearing in mind that support depends on sporting success ${ }^{37}$ and that athletes are over-motivated to achieve better marks, along with very high economic incentives and sometimes political and social pressure ${ }^{11}$.

A very important part of Sports Medicine is to take measures and propose actions to prevent or at least minimise the risks inherent in sport. What cannot be accepted is the argument that, since sport has risks, those that may arise from the medically controlled use of doping substances are accepted ${ }^{12}$. Doctors should not adds risk to 
the athlete. This goes against his professional precepts and his code of ethical conduct.

\section{The healthy sport argument}

The argument of banning doping on health grounds has been considered by supporters of liberalisation to be a false moral argument indicating that there are sports involving real health risks ${ }^{12}$

It has already been pointed out that the risk is inherent in sport and is thus accepted by society as a whole. The fight against doping seeks to avoid risks that are additional to those inherent in sport, and the argument to that effect is therefore misplaced.

Today's medical work is not the "picturesque image of an ideal harmony between beauty, strength and health devised by the first Olympic movement"12 but the work of prevention in all aspects to prevent the problem from appearing.

There is no need to insist on the principle that it should not be the doctor who favours attitudes or strategies, such as the proposal of medically-directed doping that lead a person to self-destruction.

\section{Doping substances have few health risks}

It has been indicated that the effects of doping substances are not as harmful as claimed, that there is little evidence available on the long-term effects of anabolic steroids and that the medical profession has little credibility regarding the consequences of anabolic steroid use because they are based on athlete comments and advice from other drug users ${ }^{23}$.

The scientific literature now offers many scientific evidence on health risks of prohibited substances and methods. The following description is not intended to be a comprehensive review of the harmful health effects of doping substances and methods but, it might be sufficient for the reader to appreciate the risks inherent in the use of various doping procedures.

Athletes who use doping often use a combination of several drugs in high doses, which are constantly changing, leading to interactions and counter-actions. Among the biomedical side effects of doping, cardiovascular effects are the most harmful because they can increase morbidity and mortality ${ }^{38}$ (Tables 1, 2).

Table 1. Describes the side effects of ephedrine.

\begin{tabular}{l}
\hline Side effects of ephedra and ephedrine ${ }^{39}$ \\
\hline - Arrhythmias. \\
- Sudden death. \\
- Myocardial infarction. \\
- Vasospasm. \\
- Hypertension. \\
- Myocardial hypertrophy. \\
- Cardiomyopathy. \\
- Myocardial necrosis. \\
- Cerebral vascular accident.
\end{tabular}

Table 2. Describes the side effects of anabolic androgenic steroids.

\begin{tabular}{|c|c|}
\hline \multicolumn{2}{|c|}{ Side effects of anabolic androgenic steroids $\mathrm{s}^{38-40}$. } \\
\hline Cardiovascular & $\begin{array}{l}\text { - Arrhythmias } \\
\text { - Sudden death } \\
\text { - Thrombosis } \\
\text { - Peripheral embolism } \\
\text { - Myocardial infarction } \\
\text { - Coagulation disorders } \\
\text { - Polycythemia } \\
\text { - Coronary atheromatous disease/dyslipaemia } \\
\text { - Hypertension } \\
\text { - Myocardial hypertrophy } \\
\text { - Cardiomyopathy } \\
\text { - Myocardial necrosis } \\
\text { - Cerebral vascular accident } \\
\text { - Coronary Arterial Ectasia } \\
\text { - Heart failure }\end{array}$ \\
\hline Liverworts & $\begin{array}{l}\text { - Inflammatory phenomena and cholestasis } \\
\text { - Peliosis } \\
\text { - Neoplasms }\end{array}$ \\
\hline $\begin{array}{l}\text { Neuroendocrines } \\
\text { (male) }\end{array}$ & $\begin{array}{l}\text { - Suppression of the hypothalamic-pituitary- } \\
\text { adrenal axis } \\
\text { - Hypogonadism by withdrawal AAS } \\
\text { - Gynecomastia } \\
\text { - Prostatic hypertrophy } \\
\text { - Prostate cancer }\end{array}$ \\
\hline $\begin{array}{l}\text { Neuroendocrines } \\
\text { (female) }\end{array}$ & -Virilization \\
\hline Neuropsychiatry & $\begin{array}{l}\text { - Major mood disorders: mania, hypomania, } \\
\text { depression } \\
\text { - Aggression, violence } \\
\text { - Dependence } \\
\text { - Neuronal apoptosis, cognitive deficits }\end{array}$ \\
\hline Musculoskeletal & $\begin{array}{l}\text { - Premature epiphyseal closure } \\
\text { - Tendon ruptures }\end{array}$ \\
\hline Renal & $\begin{array}{l}\text { - Acute renal failure due to rhabdomyolysis } \\
\text { - Focal segmental glomerulosclerosis } \\
\text { - Neoplasms }\end{array}$ \\
\hline Immunology & -Immunosuppressive effects \\
\hline Dermatologicals & $\begin{array}{l}\text { - Acne } \\
\text { - Stretch marks }\end{array}$ \\
\hline
\end{tabular}

The terrible consequences on the health of thousands of athletes, especially women and children, of the anabolisation programme in the former German Democratic Republic must not be forgotten ${ }^{35,41}$.

Regarding erythropoietin and similar products, miscalculations in dosage and dehydration can lead to haematocrit values as high as $80 \%$, resulting in severe hyperviscosity with risk of encephalopathy, stroke, tissue hypoxia, as well as high blood pressure and possible heart failure ${ }^{42}$. There is also a severe risk of hypercoagulability with risk of pulmonary embolism, myocardial infarction and formation of peripheral thromboembolisms. Cases of sudden death have been reported that are probably related to the above-mentioned adverse effects ${ }^{39,43}$

Excessive use of growth hormone can cause side effects such as hypertension, cardiomegaly, ventricular hypertrophy and dyslipaemia ${ }^{44}$

The adverse effects of insulin-like growth factor (IGF-1) include acromegaly, myalgia, oedema, dyspnoea and hypoglycaemia and might have cardiac effects similar to those of growth hormone ${ }^{44}$ 
Table 3. Side effects of gene doping ${ }^{45}$.

- Plasmid DNA. Immunological alterations with inflammation and fever.

- Growth hormone. Oncogenesis.

- IFG-1. Oncogenesis, development of solid cancers and increased tumour growth.

- Overexpression of Epo. Increased hematocrit, increased blood viscosity, heart overload, microcirculation block, stroke and heart failure.

- Complete blockade of myostatin activity. Decrease in mass specific muscle force and shift to a faster more glycolytic phenotype suggesting impairment of the oxidative capacity of the muscle. Decrease in mass specific muscle force and shift to a faster glycolytic phenotype suggesting impairment of the oxidative capacity of the muscle ${ }^{46}$ (effects observed in mice).

Blood doping, and also artificial oxygen carriers or plasma expanders, cause tachycardia and increased post-loading of the heart, which can lead to hypertension, myocardial infarction and heart failure $\mathrm{e}^{42}$ and an increased risk of thrombosis.

Gene therapy has a clear morbidity in humans and some risk of mortality after vascular administration. The risks of gene doping are of two types: those arising from the procedures for delivering the product and those arising from the uncontrolled expression of the genes. The risks are summarised in Table 3.

The work of Pärssinen et al. ${ }^{47}$ finds an increase in premature mortality in competitive powerlifters who used ALE with a 4.6-fold increased risk (95\% Cl 2.04-10-45; $p=0.0002$ ) compared to the group of powerlifters who had not used ALE.

\section{The use of medicines}

The use of many medicines depends on doctor's prescription. Prescription is a medical act resulting from a diagnosis. If there is no diagnosis, there is no prescription, and there can be no prescription on demand, especially if the individual is not ill, has no pathology or does not need a preventive prescription.

The Spanish Code of Medical Deontology ${ }^{48}$, which establishes compulsory rules for doctors, indicates that the primary duty of the doctor is to care for the health of the individual and will never intentionally harm the patient.

The doctor must respect the patient's refusal, in whole or in part, of treatment, but if the patient demands from the doctor a procedure which the doctor, for scientific or ethical reasons, judges to be inappropriate or unacceptable, the doctor, having been appropriately informed, is dispensed from acting.

The doctor must have the freedom to prescribe, respecting scientific evidence and authorised indications, which allows him to act independently and guarantee quality.

An additional case would be to treat the athlete to restore the alterations that occur during training, and which could show values of variables at lower than normal levels. This might happen with hormone levels after hard competition or strenuous training. It is clear that among the qualities of the sportsman or woman that can differentiate him or her from others, is his or her capacity to restore homeostasis, so therapeutic aids (hormonal contribution, for example) in this sense would be a clear interference in the normal physiological processes involved in sports practice.

Moreover, it is not deontologically acceptable that the doctor contributes fraudulently to the improvement of the athlete's performance. The assessment of the suitability to practice sport must be based on criteria of care for the health and physical and psychological integrity of the subject. In this respect, doping by sports medicine societies is also prohibited ${ }^{49,50}$.

\section{Allowing gene doping because it is unavoidable}

There is an argument for liberalisation which argues that, since gene doping is inevitable, what needs to be done is to allow it by regulating its use $\mathrm{e}^{51}$. The justification for this proposal is that the improvement that gene doping causes in the body can be described as legitimate since this intervention is not within the scope of the harm argument (because its risk is not excessive) nor does it affect the spirit of sport. At least provisionally, genetic modifications affecting the germ line should only be prohibited until scientific evidence can certify that these genetic modifications do not affect the health of the offspring.

It has already been indicated in the previous section that gene therapy is not free from significant risks and it is more than evident that the peculiarities of this therapy should be reserved not only for medical problems under strict prescription but also for truly serious diseases for which there are no other effective forms of treatment.

\section{Risks of self-medication or use of medication without a prescription}

In addition to the risks of using doping substances, there is the use of non-medically prescribed substances as is the case with opiates in adolescent women ${ }^{52}$, which has important consequences on their health and on the foetus when used in pregnancy ${ }^{53}$. There is also a high risk of neuropsychological dysfunction among students who abuse stimulants without a prescription ${ }^{54}$.

Decriminalisation is also being considered in professional and highperformance sport because the clandestine practice of doping leads to many professional sportsmen and women and aspirants to health insecurity ${ }^{13}$. Additionally, the use of doping substances, in many sports and on all continents, has become a major public health problem due to the lack of quality controls ${ }^{55}$.

The answer to these arguments is that the responsibility for clandestine use lies with those who practise it and that liberalisation would undoubtedly promote doping among young people and amateurs. The argument based on leaving it to the good judgement of athletes not to use doping in the knowledge of its negative consequences for their health is not sustainable. In fact, prohibitive and punitive strategies have shown the best results in terms of abandoning substances or actions which could endanger the health of the general population, as has been the case with smoking or road speed control. 
In cases where doping is not monitored, it is very worrying to know that up to $50 \%$ of atheltes would agree to doping in the knowledge that they would die within five years if they were sure that by doping they would achieve great success ${ }^{56}$. Thus, these circumstances are a further argument for considering that liberalising doping would increase its current negative consequences.

\section{Arguments related to sports performance}

\section{Doping products do not improve performance}

It has been argued that the banning of doping substances is incorrect and immoral since it is doubtful to produce performance improvements or are non significant to improve results in competition. In addition, it would take large cohort and double-blind studies to prove that they actually cause performance improvement $5^{57}$. However, it should be remembered that it is difficult for ethics committees to authorise studies on the effects of supra-physiological doses for nonclinically approved uses $^{58}$

It is obvious that if the effects of the different forms of doping were not effective, they would not be used. The most striking case may be the discovery that the effects of anabolic steroids are dosedependent ${ }^{59}$. There were many studies that found no effect of AAS on increasing muscle size and strength ${ }^{60,61}$, but with higher doses AAS have been found to cause a $5-20 \%$ increase in muscle strength and a $2.5 \mathrm{~kg}$ increase in body weight ${ }^{62}$.

As far as oxygen availability enhancers are concerned, the effects of blood re-infusion on exercise have been known for almost 50 years ${ }^{63}$ and recently Lundby et $a^{164}$ indicated that the effects of blood doping on performance were very significant.

\section{Doping is comparable to other performance-enhancing techniques}

It has been argued that doping is no different from performanceenhancing techniques such as shaving the body of swimmers or refractive surgery to improve visual acuity in precision sports ${ }^{57}$. Moreover, it is surprising that the use of oxygen availability enhancers, such as EPO, are banned, but that hypoxia tents or training at altitude, which have similar effects, are not ${ }^{65}$.

The answer to the first arguments is simple. Firstly, athletes have the right to have their pathologies treated, such as the correction of myopia. Secondly, the improvements in performance are marked by the rules of each sport (in swimming, shaving is allowed, but not certain swimming suits or adhesive therapy strips, for example ${ }^{66}$. With regard to the use of oxygen availability enhancers, each athlete can follow the best training to stimulate the physiological processes that improve his performance. The use of hypoxia workouts has not been forbidden, but the use of EPO and blood transfusion is prohibited because their effects do not respond to physiologically activated stimuli and therefore without control of the homeostasis processes, which can add a risk. Their use is reserved for patients generally suffering from serious illnesses.

There is no doubt that the rules in sports have a point of arbitrariness, but the interpretations of the rule make it precisely that sport and its achievements are valued ${ }^{58}$. The importance of sporting rules is easy to explain: nobody would understand if, in order to encourage basketball players, the diameter of the basket were increased to make the game easier ${ }^{58}$. JW Levine ${ }^{57}$ wondered, referring to the discussion on the liberalisation of doping, that why athletes had to use their legs if they would be go faster by cycling. Obviously, everyone understands the need for rules. The athlete needs a difficulty and the spectator values the natural aptitudes and preparation of the athlete.

\section{Matching genetic differences between athletes}

Another argument in favour of liberalisation is that doping would make it possible to even out the differences between athletes resulting from natural, genetically determined qualities, which is known as the natural lottery of the most gifted ${ }^{67}$. Genetic lottery prevent everyone from competing on the same level ${ }^{10}$.

This argument highlights the lack of awareness that in sport it is essential to exalt the diversity of natural talents and that the skills and dedication of competitors is decisive $\mathrm{e}^{58}$. Different sports emphasise different natural abilities and in this sense, differences in people's aptitude for different sports are not a reason to try to match them artificially, for example through doping, but to highlight the wide variety of sports and equally the great diversity of human beings.

Moreover, this argument is inconsistent, because if the use of doping substances were allowed, they could also be taken by the most gifted, unless these athletes were prohibited from doing so. This would mean that sporting success would be determined by the decision of the persons or bodies deciding on the use of substances. On the other hand, the doctor, who according to the promoters of this initiative would be the one to administer the substances, cannot decide who deserves to improve and who does not, nor is it up to him to level the attitudes between athletes ${ }^{31}$.

\section{Other arguments}

\section{The argument that banning encourages doping}

This argument is based on what happened at the beginning of the $20^{\text {th }}$ century in the United States of America (USA) with the dry law that prohibited the manufacture and marketing of alcohol ${ }^{68,69}$. The argument is that prohibitions have a call effect, that they promote clandestine business and that they favour the consumption of prohibited substances. It is therefore argued that doping control increases the risk by favouring the clandestine business of doping substances ${ }^{10}$.

While it may be thought that prohibition increased the consumption of alcoholic beverages, the reality is that it decreased mortality and hospital admissions due to the consequences of alcoholism, as well as annual per capita alcohol consumption to less than half of that prior to the prohibition period, and created an atmosphere of understanding of prohibition by society ${ }^{70}$. These beneficial effects were maintained after the ban was lifted ${ }^{69}$.

Furthermore, it has been considered incorrect to say that the experience of this ban would always result in failure. Subsequent experience shows that partial bans can produce substantial public health benefits at an acceptable social $\operatorname{cost}^{68}$. 
The comparison between the dry law and the ban on doping seems unfortunate and not at all comparable for two reasons. Firstly, because in the USA there has been a shift from no ban on alcohol consumption to a total ban on it. However, doping has always been banned. Furthermore, there have been bans that have proved effective, such as the ban on smoking in Spain, which has reduced the risk of people exposed to tobacco, its sale and consumption and the rates of acute myocardial infarction, ischemic heart disease and asthma71,72.

\section{Doping control increases the risks of doping}

It has been argued that doping leads to dangerous behaviour that would not occur if its use were liberalised ${ }^{12}$. For example, the detection of oil-based esters of nandrolone, which belong to a class of anabolic steroids with few side effects and little risk of liver disease, has led to the use of oral analogues with more side effects but which are eliminated more quickly, making them difficult to detect. Figure 1 lists the adverse analytical findings (AAR) ${ }^{8}$ from WADA-accredited laboratories that indicate the most commonly used parenteral AAR detections. Nandrolone is the only AEA for parenteral use that has decreased, according to the criteria expressed by Kayser et al. ${ }^{12}$, from more than 250 detections to less than 200. However, the rest of the AEA for parenteral use (methenolone, boldenone and trenbolone) have greatly increased their detections, exceeding by far the use of nandrolone and increasing the total consumption of AEA for parenteral use (in 2015 there were 176 detections of nandrolone, compared to 216 of the other three products). The use of oral AADs has also increased for most products.

It has also been argued that recombinant erythropoietin, being detectable, has led to increased use of other oxygen-transport enhancing substances with greater potential health risks ${ }^{25}$.

For these reasons, it is suggested that these consequences of anti-doping practices may cause more health problems than they are intended to prevent.

The above argument is inconsistent and infantile, and it has not been demonstrated that the use of doping substances has more risks associated with these alleged changes in use. The responsibility for the use of doping substances cannot be attributed to the fight against

Figure 1. Parenteral AAS.

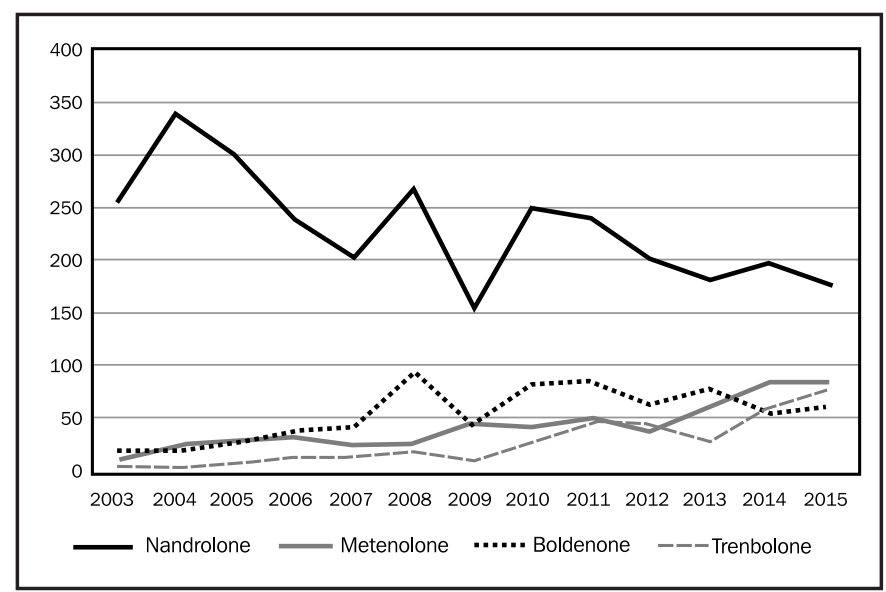

doping but to the athlete who dopes as well as to those who induce or assist him/her in doing so.

\section{The high cost of the fight against doping}

Proponents of the liberalisation of doping argue that the cost of the fight against doping is very high and that its effectiveness is questionable. Furthermore, it targets a small population group, and that this involves an ethical dilemma of greater importance and relevance than the ethical argument of anti-doping practice ${ }^{12,23}$.

We understand that the costs of the fight against doping can indeed be high. The current anti-doping policy is therefore aimed at rationalising resources and directing control strategies towards specific areas of high risk of doping 4 . But while we believe that doping cannot be entirely eradicated, the data do indicate that it has been reduced to the lowest level of all available records 8 .

Figure 2 shows the increase in HAA detections in WADA-accredited laboratories, highlighting a decrease in Olympic sports, where there is more anti-doping pressure, compared to non-Olympic sports which since 2013 are detected more than the previous ones.

Figure 3 shows that the percentage of HAA has progressively decreased from about $2 \%$ in the first half of the 2000 decade to about $1.2 \%$ nowadays. The decline is greater in Olympic sports, which are below $1 \%$ since 2008 .

We agree that the problem of doping is much more worrying among amateur athletes because they are much more numerous and outside any kind of medical control, even among very young athletes ${ }^{73-76}$.

\section{The use of anti-doping resources for a few}

It has been argued that it is ineffective to target anti-doping resources when it affects many amateurs and that doping control is targeted at very few subjects ${ }^{12}$.

The approach of liberalising doping through its prescription by specialised doctors would be more expensive, but would also justify without any arguments the use of doping methods to the whole population. Thus, this would increase their use over today's values what

Figure 2. Number of HAA sports Olympic and non-Olympic.

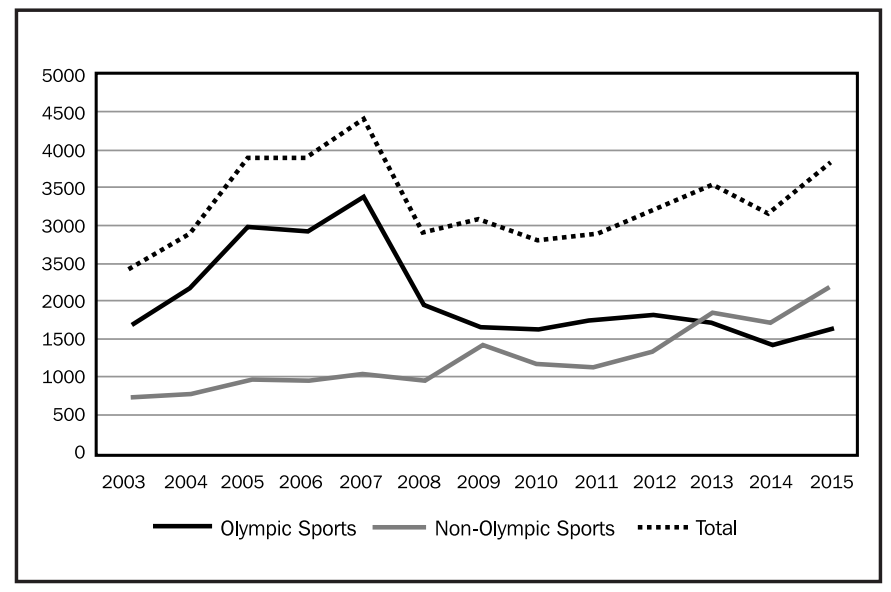


Figure 3. Percentage of HAA sports Olympic and non-Olympic.

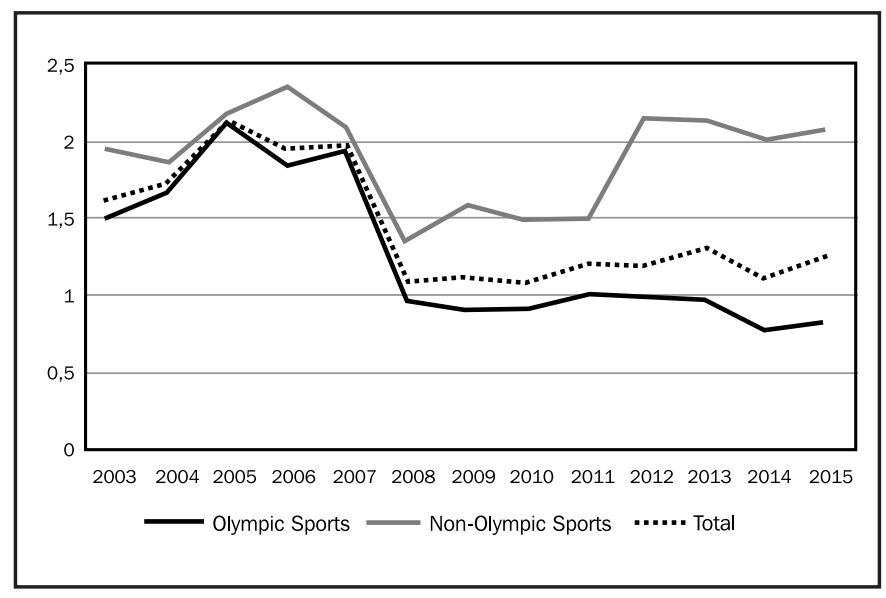

already seems very remarkable. Defending the values of sport and seeking ways of controlling the use of doping substances by amateur athletes is needed.

It has been suggested ${ }^{11}$ that the health protection arguments for banning doping are of less importance than those based on protecting sport. In this respect, it is sufficient to refer to the highest legal standard in the world, the Universal Declaration of Human Rights, which states that everyone has the right to health, medical care and health insuran$\mathrm{ce}^{77}$. Without diminishing the importance of sport as a major activity, it is not mentioned in the above declaration.

\section{The proposal to liberalise doping under medical supervision}

In the light of the above arguments, and in view of the fact that doping should be liberalised, it has been proposed that sports doctors should be able to test athletes for doping ${ }^{10-13}$. However, the risks of total permissiveness in the use of substances should be avoided, This measure would increase doping, but there would be less morbidity and mortality by increasing safety and reducing clandestinity. This would be done under the principle of non-maleficence and protection of privacy ${ }^{12}$.

It seems that the first time this argument was used was in the context of the German Democratic Republic, where there was a massive state doping system in which doctors minimised the dangers of substances, especially anabolics, as long as they were performed under medical supervision ${ }^{78,79}$, which would be less harmful than clandestine doping performed by the athlete himself.

This criterion is widespread among some sports doctors worldwide and is not an exclusive feature of East German medicine at that time. There is a culture of doping among some doctors which is not only justified by the fact that the risks are minimised by medical supervision. Perhaps the real argument lies in economic reasons, and even in the fact that the results achieved by their athletes are notorious.

Proponents of the legalisation of "medically supervised" doping believe that this relationship is comparable to the traditional doctor- sick relationship. The reality is that this relationship can subordinate medical judgment and client health to performance requirements. This flawed relationship is exacerbated when the doctor becomes dazzled by the athlete's celebrity and successes, causing the doctor to identify so strongly with the athlete's goals and to cause such satisfaction of the athlete's celebrity that he abandons medical standards in favour of the ambitions of the athlete-client who is now in charge of his medical "treatment"79. This can lead to a two-way emotional dependence when the doctor succumbs to the charismatic appeal of the athlete and the athlete reveres the doctor as if he were an infallible guru. In his memoir The Secret Race, doped cyclist Tyler Hamilton writes that the famous Italian doper Michele Ferrari "was our trainer, our doctor, our god"79,80.

The work of the doctor in competitive sport is carried out within a complex ethical framework that invites reflection, because it is not exempt from problems arising from the pressure of the interests of those involved such as the coach, the sponsors and the athlete himself to achieve results ${ }^{12}$. In this context, the role of the doctor is to preserve the athlete's autonomy, to strike a balance between performance and health and to maintain the lifestyle chosen by the athlete.

This leads to situations where optimisation of performance conflicts with the preservation of health, such as when therapeutic measures are applied to keep an athlete competing despite an injury.

While not an easy task, this problem is addressed by maintaining proportionality between the benefits and risks reported to the athlete and the answer to the difficult question of what kind of health risks are acceptable for the athlete to assume.

Regarding performance enhancement, even using currently prohibited procedures, supporters of the liberalisation of doping argue that, in line with the principle of autonomy, the doctor should be at the athlete's service in order to enhance performance. As a result, a doctor in the role of performance enhancer must be responsible for the harmful effects of the use of any medical technology. This would be analogous to the usual role of physicians. They are free in their choice of intervention, pharmacological or otherwise, as long as it is in accordance with current medical knowledge and without iatrogenic disordered effects. Rather than speculating on anti-doping testing procedures, resources should be invested in protecting the integrity of physicians making such judgements.

If doping were permitted under an ethical structure based on the principle of non-maleficence, there would probably be an increase in the use of ergogenic aids, i.e. products currently considered as doping, but this would not lead to an increase in morbidity and mortality ${ }^{12}$. In order to differentiate this strategy from the one implemented in the former German Democratic Republic ${ }^{35,41}$, it would be necessary to ensure better information for athletes on the risks they would have and to guarantee the transparency of this practice, thus preventing a given nation from having advantages for its athletes. Furthermore, doping in a non-clandestine manner could have positive effects on the restricted world of elite sport. In fact, doping practices in the world of amateur sport could be less dangerous and thus the overall incidence of health problems caused by doping could be reduced.

This system of doping supervised and carried out by doctors would not lead to total liberalisation in order to avoid health risks. In fact, supporters of liberalisation recognise that doping has risks, even 
fatal risks, which are considered too high a price to pay for sporting success, even in a society which allows self-destructive behaviour ${ }^{31}$. A certain level of ban would therefore remain. Determining what the limit of the ban should be is very difficult, since not many consequences of the use, especially of the new banned substances, are known. In such cases, medicine dictates the prudence that an unresearched substance should not be considered safe or without side effects, even if its side effects are presumed to be rare.

In case of legalisation, the permissible limits of the use of these substances should be determined outside the individual judgement of the physician. If this were the case, athletes would go to the most daring doctor who would give more products or in higher doses, which would cancel out the principle of equal opportunity, as well as increase the risk of side effects. This would require new rules and an international authority to monitor them. The limit on the use of substances, according to the advocates of liberalisation, would be "safety"5, which would entail maintaining regulations and a control system that, according to the promoters, should be more frequent and complex, which would increase expenditure, and which would furthermore add to the risk of using prohibited substances even if they were under control ${ }^{10}$.

The worst thing would be that all athletes would be forced to take drugs, since the rest would do so and it would be impossible to achieve sporting results without taking drugs.

Another likely result would be an acceleration and aggravation of the pressures on athletes to use higher doses and new combinations of substances in order to stay ahead of competitors. The same dynamic, similar to the arms race, which currently motivates some athletes to take prohibited substances, would lead them to more extreme forms of use if the bans were lifted. It is likely that one of the supposed advantages of lifting the ban (ths safer use) would be offset or overcome by the drive to increasingly use combinations of substances for which it is not known whether they are safe to use. The unknown risks to athletes currently using these substances would be multiplied. As irresponsible experimentation aimed at boosting athletic performance spreads from elite athletes to amateurs who admire and want to emulate their heroes, the public health impact would be amplified.

The dynamics of competition in sport, the effort to constantly seek to gain a competitive advantage, means that, without effective antidoping programmes, athletes will be driven to adopt an increasingly extreme and experimental doping regime in the interests of competitive advantage. No one can predict with certainty the outcome of such a "race of doping substances", but it is almost certain that it will not be benign and that the health of sportsmen and women, elite or amateur, adults or young people, will be put at risk ${ }^{58}$.

It is obvious that the authors of the paper are absolutely against the establishment of a doping system by doctors.

\section{Effects of liberalisation on children and adolescents}

Children and adolescents deserve special attention and it is a medical obligation to provide them with special surveillance and care to avoid the possible negative consequences of practising sport. Surprisingly, there are supporters of the liberalisation of doping who say that if children are allowed to train as professional athletes, then they should be allowed to take the same medication, provided that it is not more dangerous than training ${ }^{10,81}$.

The boundless willingness of doping would have devastating effects. The elimination of the ethical principles of fair play, in an activity in which young people willingly accept the rules that sport represents in its most noble essence, would cause society to lose a large part of these principles and the value of effort and talent in young athletes would be lost. Moreover, it would not be possible to ban doping among young sportsmen and women as long as it was authorised among adults and would encourage the already high level of use of doping substances among the most vulnerable sections of society, such as adolescents and other groups at risk ${ }^{82}$.

From a medical point of view, this reasoning is absolutely unacceptable, because the immediate and long-term effects of pharmacological interventions such as those carried out in doping procedures on under-18 athletes (the cut-off age in most federations) are not known.

Furthermore, training and competition need not be similar to that of adults. They might be harmful and can be changed, while the effects of doping cannot be ignored.

The only reasonable behaviour for people who are concerned about the welfare of children and who wish to preserve the "educational credibility" of sport is to ensure that the unavoidable risks are minimised as much as possible and to avoid the clearly avoidable risks associated with sport for children, including the risks associated with doping ${ }^{31}$. Attempting to justify an additional, pointless evil by pointing to the existence of another inevitable evil is not a persuasive argument.

\section{Medical ethics}

The principles of the medical profession come from the Hippocratic Oath, dating from the $12^{\text {th }}$ century, which implies a commitment by the physician to society. According to these principles, which are fully in force, the profession is exercised for the benefit of the patient and without causing him/her any harm ${ }^{83}$.

The Geneva Convention, in various adaptations, establishes as inherent duties of the physician, among others, that he must look after the health of the patient, maintain the noble traditions of the medical profession and not use medical knowledge to contravene human laws, indicating that all this is destined to the fulfilment of the purposes of medicine, among which the prevention of disease and the promotion and preservation of health are the principal ones ${ }^{83}$.

The evolution of society means that the principles of the Hippocratic J have been adapted to the present day in the following aspects, among others ${ }^{83}$ :

- The well-being of the patient which takes precedence over other values and which requires that the interest of the patient alone be served. It should not be influenced by social, administrative or other currents or pressures (including economic ones, as is the case with doping). 
- Patient autonomy. Physicians must respect the decisions of their patients, provided that they do not violate medical ethics or lead to improper practice.

- Social justice. The doctor is responsible for promoting justice within the health system and also for denouncing injustices or possible discrimination in the provision of health services based on unjustifiable principles (gender, race... or any other, as is the case with doping).

- Appropriate relationships with patients. The aim is not to maintain an advantageous relationship with patients. The situation of dependency with the doctor can lead to illegal and unethical situations of gain, on any level. This could happen in the case of physician-sponsored doping.

- Improving access to health care. Its actions include health promotion and disease prevention.

- Professional responsibilities. Not only leading to the continuous improvement of care and the qualities of care (quality, efficiency, equity, etc.) but they also seek to uphold the principles of the medical profession. They must participate in the establishment of controls in the exercise of the profession in accordance with certain values, and in the correction of deviations if they occur. This means that physicians have individual responsibility for the practice of their profession, but also collective responsibility.

Doctors must reaffirm their loyalty to the principles and commitments of professionalism which are their principles and which allow them to exercise their profession with dignity.

The Spanish Law ${ }^{84}$ indicates several mandates that must be taken into account by doctors who will be guided in their actions by the service to society, the interest and health of the citizen to whom the service is provided, the rigorous fulfilment of the deontological obligations, determined by the professions themselves in accordance with the legislation in force, and the criteria of standard practice or, where appropriate, the general uses proper to their profession.

It is essential to emphasise these later concepts of prevention, promotion and conservation of health, because they include as the object of the doctor's work not only patients or the sick, but also healthy individuals, including sportsmen and women ${ }^{85}$, who are the special object of the work of sports medicine ${ }^{86}$

To satisfy these principles, not everything is valid. Physicians carry out their profession through a commitment to medical science and to the sick, and these commitments are established through a contract with society. The basis of that contract is professionalism, the principles of which must be respected by the physician himself and by society.

It has been said that the health risk of doping, under appropriate supervision (in which the doctor would facilitate the doping procedure and would play a very important role), would be easier to justify and that the doctor cannot simply assume that doping is, per se, more dangerous than the risks of participating in elite sport ${ }^{12}$. The doctor does his job by treating the athlete, like any patient, for any medical problem, whether or not it stems from the risk of the sport. What is not part of their job or ethics is the assumption that it may indicate patterns of doping in elite sport, since the risks are lower than those of some sports for their own practice.

Although this paper focuses on the medical aspects of the controversy over the use of prohibited substances, including the ethical aspects that have to do with medicine, it does not seem inappropriate to recall that the vast majority of athletes practices sport in search of the values it embodies. In addition, spectators enjoy and admire the forms of human excellence that are developed in this activity ${ }^{58}$. Moreover, the values of sport continue to be a model for most citizens ${ }^{31}$.

Consideration of the risks of doping relates to the question of whether the doctor's actions in this context are consistent with his professional essence of establishing the health of the patient as his first concern, in a similar way to what happens with cosmetic surgery. In this case, when surgery is considered, there is an inevitable risk from the surgery itself, but in the case of sports performance enhancement the risks of doping substances are unnecessary.

In contrast, the risks involved in the use of performance enhancing drugs in sport are unnecessary, which means that doctors would be unnecessarily exposing their patients to risks in an attempt to make sport more attractive. If doctors were to administer unauthorised doping agents, they would be involved in a violation of the rules of sport ${ }^{31}$.

\section{Conclusions}

The doping control system, although it has been greatly improved in recent years, needs to be refined in certain respects such as the system for detecting substances and the reasons for their inclusion on the prohibited lists. However, partial liberalisation of doping under supervision would not only fail to solve the problem but would aggravate it by increasing the consumption of substances and spreading it throughout the athlete population.

Moreover, the doctor is a professional whose work is much more important than satisfying the impulse and pretensions of some individuals, and should not be separated from his or her deontologica principles, which is the only way to make medicine a respected and extraordinarily useful profession for society.

The authors declare no conflict of interest and do not have any financial disclosures.

\section{Conflict of interest}

The authors do not declare a conflict of interest.

\section{Bibliography}

1. Manonelles P, Pigozzi F, Terreros JL. Un poco de historia. En: Guía de prevención del do paje. Lo que el deportista debe conocer sobre el dopajey su prevención. Pedro Manonelles Marqueta. Antonio Luque Rubia. Murcia. UCAM Universidad Católica San Antonio de Murcia. 2015;21-36.

2. Dvorak J, Saugy M, Pitsiladis YP. Challenges and threats to implementing the fight against doping in sport. Br J Sports Med. 2014;48:807-9.

3. International Convention Against Doping In Sport. UNESCO. París, 19 de octubre de 2005.

4. World Anti-Doping Code. World Anti-Doping Agency. Montreal. 2015

5. Striegel H, Ulrich $R$, Simon P. Randomized response estimates for doping and illicit drug use in elite athletes. Drug Alcohol Depend. 2010;106:230-2.

6. De Hon $\mathrm{O}$, Kuipers $\mathrm{H}$, van Bottenburg M. Prevalence of doping use in elite sports: a review of numbers and methods. Sports Med. 2015;45:57-69.

7. Pitsiladis Y, Ferriani I, Geistlinger M, de Hon O, Bosch A, Pigozzi F. A Holistic antidoping approachfor a fairer future for sport. Curr Sports Med Rep. 2017;16:222-4. 
8. Anti-doping testing figures. WADA-AMA. (consultado 01/08/2017). Disponible en:https://www.wada-ama.org/en/resources/laboratories/anti-doping-testing-figures.

9. Petróczi A, Aidman EV, Hussain I, Deshmukh N, NepuszT, Uvacsek M, Tóth M, Barker J, Naughton DP. Virtueor pretense? Looking behind self-declared innocence in doping. PLoSOne. $2010 ; 5:$ e10457.

10. Savulescu J, Foddy B, Clayton M. Why we should allow performance enhancing drugs in sport. Br J Sports Med. 2004;38:666-70.

11. Pérez Triviño JL. El dopaje: una visión alternativa. El Cronista del Estado social y democrático de Derecho. 2013;35:1-32.

12. Kayser B, Mauron A, Miah A. Currentanti-doping policy: a critical appraisal. BMCMedical Ethics. 2007;8:2.

13. Vicente Pedraz M. Debate sobre salud pública y despenalización del dopaje. Rev Saúde Pública. 2013;47:1011-4

14. Laure P. Doping: epidemiologica Istudies. Presse Med. 2000;29:1365-72.

15. Laure $P$, LecerfT, Friser $A$, Binsinger C. Drugs, recreational drug use and attitudes towards doping of high school athletes. Int J Sports Med. 2004;25:133-8.

16. Thiblin I, Petersson A. Pharmacoepidemiology of anabolic androgenic steroids: a review. Fundam Clin Pharmacol. 2005; 19:27-44.

17. Alaranta A, Alaranta H, Holmila J, Palmu P, Pietila K, Helenius I. Self-reported attitudes of elite athletes towards doping: differences between type of sport. Int J Sports Med. 2006;27:842-6.

18. Dietz P, Dalaker R, Letzel S, Ulrich R, Simon P. Analgesics use in competitive triathletes: its relationship to doping and on predicting it susage. J Sports Sci. 2016;34:1965-9.

19. Pesta DH, Angadi SS, Burtscher M, Roberts CK. The effects of caffeine, nicotine, ethanol, and tetrahydrocannabinol on exercise performance. Nutr Metab (Lond). 2013;10:71.

20. Paluska SA. Caffeine and exercise. Curr Sports Med Rep. 2003;2:213-9.

21. Del Coso J, Muñoz G, Muñoz-Guerra J. Prevalence of caffeine use in elite athletes following its removal from the World Anti-Doping Agency list of banned substances. Appl Physiol Nutr Metab. 2011;36:555-61.

22. Monitoring program. WADA-AMA. (consultado 12/08/2017). Disponible en: https:// www.wada-ama.org/en/resources/science-medicine/monitoring-program.

23. Kayser B, Smith AC. Globalisation of anti-doping: the reverse side of the medal. BMJ. 2008;337:a584.

24. Terapeutic use exemptions. WADA-AMA. Consultado 16/08/2017. Disponible en: https://www.wada-ama.org/en/what-we-do/science-medical/therapeutic-useexemptions.

25. Schumacher YO, Ashenden M. Doping with artificial oxygen carriers: an update. Sports Med. 2004;34:141-150.

26. Naranjo Orellana J, Centeno Prada RA, Carranza Márquez MD. Use of beta2 agonists in sport: are the present criteria right? Br J Sports Med. 2006;40:363-6.

27. Overbye $M$, Wagner $U$. Between medical treatment and performance enhancement: an investigation of how elite athletes experience Therapeutic Use Exemptions. Int $J$ Drug Policy. 2013;24:579-88.

28. Fuentes E. Entrevista en Marca. 2013. Consultado el 22-8-2107. Disponible en: http:// www.marca.com/2013/04/04/ciclismo/1365029848.html.

29. Pérez Triviño JL. ¿Qué hay de malo en el dopaje?. Consultado el 6-6-2107. Disponible en: http://www.jperezt.com/blog-/que-hay-de-malo-en-el-dopaj.html.

30. Manonelles Marqueta P, De Teresa Galván C, Alacid Cárceles F, Álvarez Medina J, Del Valle Soto M, Gaztañaga Aurrekoetxea T, Gondra del Río J, Luengo Fernández E, Martínez Romero JL, Palacios Gil-Antuñano N. Deporte recreacional saludable. Documento de consenso de la Sociedad Española de Medicina del Deporte (SEMED-FEMEDE). Arch Med Deporte. Volumen 2016; 33, Supl 2: 8-40.

31. Wiesing U. Should performance-enhancingdrugs in sport be legalized under medical supervision? Sports Med. 2011;41:167-76.

32. Ramos Gordillo AS. Lucha contra el dopaje como objetivo de salud. Adicciones. 1999; 11:299-310.

33. López Frías FJ. Una propuesta dialógica para el debate en torno al dopaje. Ágora Papeles de Filosofía. 2015;34:145-65.

34. Kondric M, Sekulic D, Petroczi A, Ostojic L, Rodek J, Ostojic Z. Is there a danger for myopia in anti-doping education? Comparative analysis of substance use and misuse in Olympic racket sports calls for a broader approach. Subst Abuse Treat Prev Policy. 2011;6:27.

35. Franke WW, Berendonk B. Hormonal doping and androgenization of athletes: a secret program of the German Democratic Republic government. Clin Chem. 1997;43:1262-79.

36. Verroken M. Ethical aspects and the prevalence of hormone abuse in sport. J Endocrinol. 2001;170:49-54.

37. Loland S. The ethics of performance-enhancing technology in sport. Journal of the Philosophy of Sport. 2009; 36:152-65.
38. Deligiannis A, Björnstad H, Carre F, Heidbüchel H, Kouidi E, Panhuyzen-Goedkoop NM, Pigozzi F, Schänzer W, Vanhees L; ESC Study Group of Sports Cardiology. ESC study group of sports cardiology position paper on adverse cardiovascular effects of doping in athletes. Eur J Cardiovasc Prev Rehabil. 2006;13:687-94

39. Dhar R, Stout CW, Link MS, Homoud MK, Weinstock J, Estes NA 3rd. Cardiovascular toxicities of performance-enhancing substances in sports. Mayo Clin Proc. 2005;80:1307-15.

40. Pope HG Jr, Wood Rl, Rogol A, Nyberg F, Bowers L, Bhasin S. Adverse health consequences of performance-enhancing drugs: an Endocrine Society scientific statement. Endocr Rev. 2014;35:341-75.

41. Tuffs A. Doped East German athletes to receive compensation. BMJ. 2002;324:1544.

42. Wagner KF, Katschinski DM, Hasegawa J, Schumacher D, Meller B, Gembruch U, Schramm U, Jelkmann W, Gassmann M, Fandrey J. Chronic in born erythrocytosis leads to cardiac dysfunction and premature death in mice overexpressing erythropoietin. Blood. 2001;97:536-42.

43. Heuberger JA, Cohen Tervaert JM, Schepers FM, Vliegenthart AD, Rotmans JI, Daniels $J M$, Burggraaf J, Cohen AF. Erythropoietin doping in cycling: lack of evidence for efficacy and a negativerisk-benefit. Br J Clin Pharmacol. 2013;75:1406-21.

44. Meyers DE, Cuneo RC. Controversies regarding the effects of growth hormone on the heart. Mayo Clin Proc. 2003;78:1521-6.

45. Wells DJ. Gene doping: the hype and the reality. Br J Pharmacol. 2008;154:623-31

46. Amthor H, Macharia R, Navarrete R, Schuelke M, Brown SC, Otto A, Voit T, Muntoni F, Vrbóva G, Partridge T, Zammit P, Bunger L, Patel K. Lack of myostatin results in excessive muscle growth but impaired forcé generation. Proc Natl Acad SciU SA. 2007;104:1835-40.

47. Pärssinen M, Kujala U, Vartiainen E, Sarna S, Seppälä T. Increased premature mortality of competitive powerlifters suspected to have used anabolic agents. Int I Sports Med. 2000;21:225-7.

48. Código de Deontología Médica. Guía de ética médica. Consejo General de Colegios Oficiales de Médicos. Organización Médica Colegial. Madrid. Julio 2011. Consultado 5 de junio de 2017. Disponible en: https://www.cgcom.es/sites/default/files/codigo_deontologia_medica.pdf.

49. Código ético en Medicina del Deporte de la Federación Española de Medicina del Deporte. Arch Med Deporte. 2010; 139: 347-8.

50. Code of Ethics. International Federation of Sports Medicine. Consultado 11 de agosto de 2017. Disponible en:http://www.fims.org/files/8214/1933/5848/FIMSCodeOfEthics.pdf.

51. Pérez Triviño JL. Gene doping and the ethics of sport: between enhancement and post humanism. Int J Sports Science. 2011;1:1-8.

52. McCabe SE, West BT, Veliz P, McCabe W, Stoddard SA, Boyd CJ. Trends in medical and nonmedical use of prescription opioids among US adolescents: 1976-2015. Pediatrics. 2017;139. pii: e20162387.

53. (ACOG Committee on Health Care for Underserved Women; American Society of Addiction Medicine. ACOG Committee Opinion No. 524: Opioid abuse, dependence, and addiction in pregnancy. Obstetrics and Gynecology. 2012;119:1070-6.

54. Wilens TE, Carrellas NW, Martelon M, Yule AM, Fried R, Anselmo R, McCabe SE. Neuropsychological functioning in college students who misuse prescription stimulants. Am J Addict. 2017;26:379-387.

55. Catlin DH, Fitch KD, Ljungqvist A. Medicine and science in the fightagainst doping in sport. J Intern Med. 2008;264:99-114.

56. Connor JM, Mazanov J. Wouldyou dope? A general population test of the Goldman dilemma. Br J Sports Med. 2009;43:871-2.

57. Shuster S, Devine JW. The banning of sportsmen and women who fail drug tests is unjustifiable. J R Coll Physicians Edinb. 2013;43:39-43.

58. Murray TH. Defender los valores y la ética del deporte: la relación entre la lucha contra el dopaje y los valores deportivos y la ética. UNESCO. SHS/2010/ $\mathrm{PI} / \mathrm{H} / 1$. (consultado 01/08/2017). Disponible en: http://unesdoc.unesco.org/ images/0018/001884/188404s.pdf.

59. Bhasin S, Storer TW, Berman N, Callegari C, Clevenger B, Phillips J, Bunnell TJ, Tricker R, Shirazi A, Casaburi R. The effects of supraphysiologic doses of testosterone on muscle size and strength in normal men. NEngl J Med. 1996;335:1-7.

60. Elashoff JD, Jacknow AD, Shain SG, Braunstein GD. Effects of anabolic androgenic steroids on muscular strength. Ann Intern Med. 1991;115:387-93.

61. VanHelder WP, Kofman E, Tremblay MS. Anabolic steroids in sport. Can J Sport Sci. 1991;16:248-57

62. Hartgens $\mathrm{F}$, Kuipers $\mathrm{H}$. Effects of androgenic-anabolicsteroids in athletes. Sports Med. 2004;34:513-54.

63. Ekblom B, Goldbarg AN, Gullbring B. Response to exercise after blood loss and reinfusion. J Appl Physiol.1972;33:175-80. 
64. Lundby C, Robach P, Saltin B. The evolving science of detection of 'blood doping'. $\mathrm{Br}$ J Pharmacol. 2012;165:1306-15.

65. Lippi G, Franchini M, Guidi GC. Prohibition of artificial hypoxic environments in sports: health risks rather than ethics. Appl Physiol Nutr Metab. 2007;32:1206-7.

66. FINA requirements for swimwear approval (FRSA). Regulations valid for swimwear to be approved with ffect from January 1, 2017. Consultado 28/7/2017. Disponible en: http://www.fina.org/sites/default/files/frsa.pdf.

67. Foddy B. Sabulescu J. Ethics of performance enhancement in sport: drugs and gene doping. In: Ashcroft RE, Dawson A, Draper H, et al., editors. Principles of health care ethics. 2nd. Ed. London: Wiley, 2007:511-20.

68. Hall W. What are the policy lessons of National Alcohol Prohibition in the United States, 1920-1933? Addiction. 2010;105:1164-73

69. Burnham JC. New perspectives on the prohibition 'Experiment' of the 1920's," Journal of Social History 1968; 2: 51-68; Clark, Deliver us from evil, 145-158; Kerr, Organizing for Prohibition, 276-277: Tyrrell, "US Prohibition Experiment," 1406.

70. Blocker JS Jr. Didprohibition really work? Alcohol prohibition as a public health innovation. Am J Public Health. 2006;96:233-43

71. Ministerio de Sanidad, Servicios Sociales e Igualdad. Informe a las Cortes Generales de evaluación del impacto sobre la salud pública de la Ley 42/2010. 2011. (Consultado 19/07/2017) Disponible en: https://www.msssi.gob.es/ciudadanos/proteccionSalud/ tabaco/docs/Informe_Impacto_Salud_Ley_Tabaco.pdf.

72. Pinilla J, Abásolo I. The effect of policies regulating tobacco consumption on smoking initiation and cessation in Spain: is it equal across socioeconomic groups? Tob Induc Dis. 2017;15:8

73. Laure $P$, Binsinger $C$. Doping prevalence among preadolescent athletes: a 4-year follow-up. Br J Sports Med. 2007;41:660-663.

74. Miah A. Doping and the child: an ethical policy for the vulnerable. Lancet. 2005; 366:874-876.

75. DuRant RH, Rickert VI, Ashworth CS, Newman C, Slavens G. Use of multiple drugs among adolescents who use anabolic steroids. N Engl J Med. 1993; 328:922-6.
76. Reardon $\mathrm{CL}$, Creado S. Drug abuse in athletes. Subst Abuse Rehabil. 2014;5:95-105.

77. Declaración Universal de los Derechos Humanos, proclamada por la Asamblea Genera de las Naciones Unidas el 10 de diciembre de 1948. Consultado el 12-8-2107. Disponible en:http://www.cnrha.msssi.gob.es/bioetica/pdf/Universal_Derechos_Humanos.pdf.

78. Reinold M. Doping in Deutschland von 1950 bis heute aus historisch-soziologischer Sicht im Kontext ethischer Legitimation. Humboldt-Universität zu Berlin/Westfälische Wilhelms-Universität Münster; Consultado 17/04/2013. Disponible en: http://www. bisp.de/SharedDocs/Downloads/Aktuelles/Stellungnahme_BISp_DiD_2013_27_08. pdf?_blob=publicationFile. Consultado: 7/08/2017.

79. Hoberman J. Physicians and the sports doping epidemic. Virtual Mentor. 2014;16:570-4

80. Hamilton T, Coyle D. the secretrace: inside the hidden world of the Tour de France: doping, cover-ups, and winning at all costs. New York: Bantam Books, 2012:102, citado en Hoberman J. Physicians and the sports doping epidemic. Virtual Mentor. 2014;16:570-4.

81. ZECO. entrale Kommission zur Wahrung ethischer Grundsatze in der Medizin und ihren Grenzgebieten (Zentrale Ethikkommission) bei der Bundesarztekammer. Doping und arztliche Ethik. Deutsches Arzteblatt 2009; 106: A 360-4. Citado en:Wiesing U. Should performance-enhancing drugs in sport be legalized under medical supervision? Sports Med. 2011:41:167-76

82. Baron DA, Martin DM, AbolMagd S. Doping in sports and its spread to at-risk populations: an international review. World Psychiatry. 2007;6:118-23.

83. Núñez-Cortés JM, Del Llano Señarís JE. Ser médico. Los valores de una profesión. 2a ed 2012. Madrid. Unión Editorial.

84. Ley 44/2003, de 21 de noviembre, de ordenación de las profesiones sanitarias. $B O E$ núm. 280, sábado 22 noviembre 2003. 41442-41458.

85. Ley 41/2002, de 14 de noviembre, básica reguladora de la autonomía del paciente y de derechos y obligaciones en materia de información y documentación clínica. BOE núm. 274, viernes14 noviembre 2002. 40126-40132

86. Frontera W. Anoverview of Sports Medicine. On: International Federation of Sports Medicine. International Sports Medicine Directory. Champaign. Human Kinetics. 2001;3-9. 


\section{POSTGRADOS OFICIALES: SALUD Y DEPORTE}

\section{Espiritu

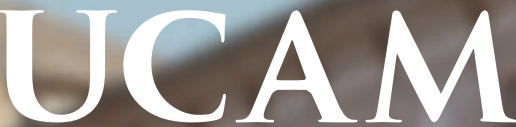

Espíritu Universitario
Miguel Ángel López

Campeón del Mundo en 20 km. marcha (Pekín, 2015)

Estudiante y deportista de la UCAM

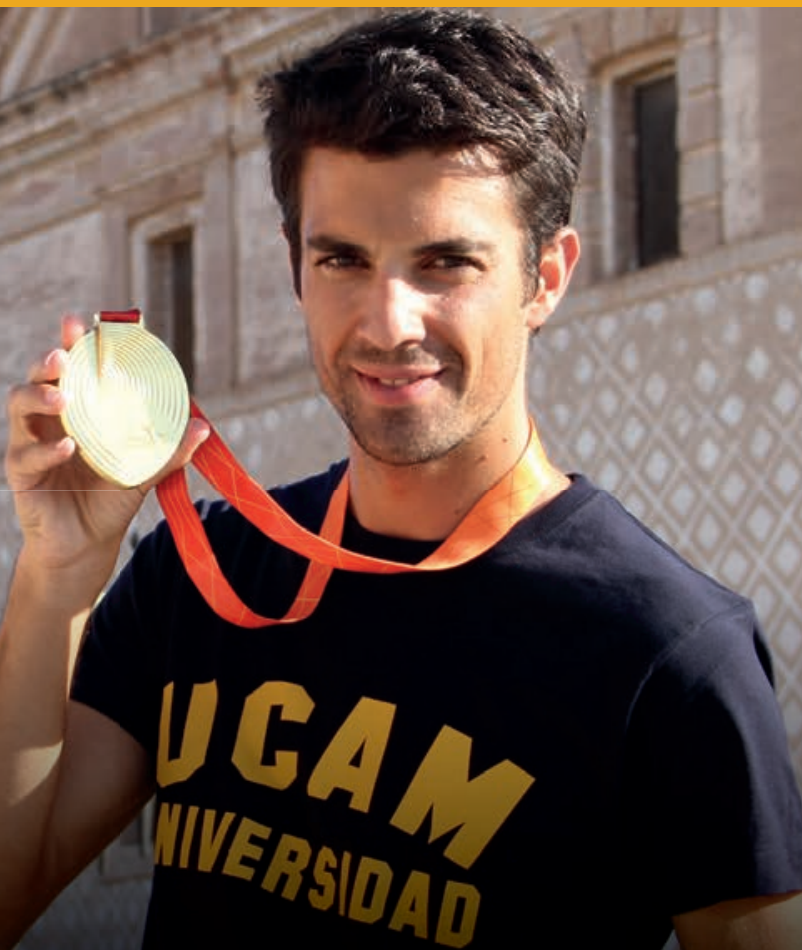

- Actividad Física Terapéutica (2)

- Alto Rendimiento Deportivo:

Fuerza y Acondicionamiento Físico (2)

- Performance Sport:

Strength and Conditioning (1)

- Audiología (2)

- Balneoterapia e Hidroterapia (1)

- Desarrollos Avanzados

de Oncología Personalizada Multidisciplinar (1)

- Enfermería de Salud Laboral (2)

- Enfermería de Urgencias,

Emergencias y Cuidados Especiales (1)

- Fisioterapia en el Deporte (1)

- Geriatría y Gerontología:

Atención a la dependencia (2)
- Gestión y Planificación de Servicios Sanitarios (2)

- Gestión Integral del Riesgo Cardiovascular (2)

- Ingeniería Biomédica (1)

- Investigación en Ciencias Sociosanitarias (2)

- Investigación en Educación Física y Salud (2)

- Neuro-Rehabilitación (1)

- Nutrición Clínica (1)

- Nutrición y Seguridad Alimentaria (2)

- Nutrición en la Actividad Física y Deporte (1)

- Osteopatía y Terapia Manual (2)

- Patología Molecular Humana (2)

- Psicología General Sanitaria (1) 